\title{
Pengaruh Perspektif Pemberdayaan Perempuan dalam Kebangkitan Ekonomi Lokal: Industri Tempe Sagu di Dusun Mrisi-Yogyakarta
}

\author{
Demeiati Nur Kusumaningrum ${ }^{1}$
}

\begin{abstract}
Abstrak
Kosmopolitanisme Hak Asasi Manusia (HAM) menempatkan isu kesetaraan gender menjadi penting bagi studi politik-ekonomi pembangunan internasional. PBB melalui UNDP dan UN Woman menekankan peran perempuan tidak hanya sebagai subjek pembangunan daerah. Perempuan memiliki hak dan kesempatan yang sama dengan kaum pria untuk memaksimalkan potensinya dalam pembangunan dan terlibat secara aktif untuk merencanakan masa depannya. Tulisan ini mengamati berkembangnya UKM Kripik Tempe Sagu di Dusun Mrisi, Bantul, DIY yang memberi makna bagi pengembangan ekonomi pedesaan. Usaha ini didirikan pada tahun 2012 dan mampu meraih omzet 50-60 juta per bulan dengan mempekerjakan hanya 3 laki-laki dan 6 perempuan. Tulisan menggambarkan bagaimana potensi komunitas perempuan berpendidikan rendah mampu ditransformasikan sebagai penggerak roda perekonomian pedesaan. Tulisan ini merupakan penelitian kualitatif, dengan teknik pengumpulan data melalui observasi, wawancara dan studi kepustakaan. Hasil penelitian menunjukkan pemilik UKM yang merupakan individu bependidikan tinggi mengadopsi perspektif pemberdayaan perempuan yang dimaknai sebagai kebermanfaatan bagi sesama dan inovasi berkelanjutan demi pembangunan desa. Dengan mengembangkan potensi iburibu rumah tangga, UKM ini tidak hanya mampu meningkatkan kesejahteraan bagi pemilik dan pekerja tapi juga menjadi sentra pendidikan, studi banding bagi UKM lain di Indonesia, representasi pembinaan dari Dinas Koperasi dan Pemberdayaan UKM Kab. Bantul, dan aktif mengikuti pameran-pameran UKM seperti Bantul Expo. Tantangan normatif-kultural di mana istri pada umumnya tidak bekerja dan merawat anak dapat diatasi dengan membangun jam kerja yang ramah keluarga serta komunikasi yang efektif dengan masyarakat sekitar.
\end{abstract}

Kata-kata Kunci: ekonomi pedesaaan, kesetaraan gender, pember dayaan per empuan

\begin{abstract}
Cosmopolitanism Human Rights put the issue of gender equality to be important for the study of global political development. United Nations through UNDP and UN Women stressed the role of women as a subject of regional development. Women have the same rights and opportunities as men to maximize their potential in development and actively involved to plan its future. This article looks at the development of SMEs named Kripik Tempe Sagu at Kabupaten Bantul, Yogyakarta which gives meaning to the development of the rural economy. This business was founded in 2012 and is able to achieve a turnover of 50-60 million per month by employing only 3 males and 6 females. This paper illustrate how the potential community of low-educated women were able to be transformed as the driving wheel of the rural economy. It is a qualitative research by descriptive method of analysis. The data and information obtained from observation, interview and literature study. The results explained that SME owner is an individual that has high decree of education background so that, she adopted the perspective of women's empowerment is understood as how she share knowledge and benefits for others and bring sustainability innovation for the sake of rural development improvement. By improving the potential of women households, the SMEs economic activities are not only able to improve the welfare of the owners and workers but also become a center of education, study visits for other SMEs in Indonesia. Normative-cultural challenges where wives generally do not work and care for children can be overcome by building a family-friendly working hours and effective communication with the surrounding community.
\end{abstract}

Keywords: rural economy, gender equality, women's empowerment

${ }^{1}$ Ketua Pusat Kajian Sosial dan Politik (PKSP), Fakultas Ilmu Sosial dan Ilmu Politik, Universitas Muhammadiyah
Malang. Kampus III Universitas Muhammadiyah Malang, Jalan Raya Tlogomas No. 246 Malang 65144, Jawa Timur. 


\section{Pendahuluan}

Sejarah telah mencatat bagaimana perempuan menjadi kaum minoritas. Kita pun mengetahui Perang Dunia dan beberapa perang sipil di berbagai wilayah sebelum tahun 1990 , menghasilkan fenomena ironis di mana perempuan merupakan fasilitas seksual para serdadu dan layak untuk diperjualbelikan sebagai budak. Periode revolusi industri di mana negara-negara Eropa termasuk Inggris turut meneguhkan kekuatan perekonomiannya yang berorientasi ekspor, pernah melibatkan anak-anak termasuk perempuan sebagai tenaga kerja. Beberapa film Barat telah mengisahkan betapa perempuan tidak hanya sebagai korban tetapi juga komoditas perdagangan. Namun melalui tulisan ini, kaum perempuan mampu menjadi agen perubahan sosial bahkan penggerak ekonomi pedesaan.

Organisasi Perserikatan BangsaBangsa $(2010)^{2}$ telah mengakui kesetaraan gender sebagai bagian dari nilai-nilai Hak Asasi Manusia (HAM). Berbagai kesepakatan PBB memberikan pernyataan yang jelas mengenai hak perempuan untuk bebas dari masalah diskriminasi. Hal ini tertuang dalam Universal Declaration of Human Rights (UDHR) tahun 1948, International Convenants on Civil and Political Rights (ICCPR) tahun 1976, dan Economic, Social and Cultural Rights (ICESCR). The Convention on the Elimination of All Forms of Discrimination against Women (CEDAW), diadopsi oleh Majelis Umum PBB tahun 1979 memandatkan penghapusan segala bentuk diskriminasi terhadap perempuan dan menjamin kesetaraan gender pada ruang privat maupun publik serta menghilangkan stigma-stigma peran berbasis gender. Pemerintah pada tahun 1995 di Beijing membahas rencana teknis terkait upaya-upaya dalam memperjuangkan standart kesetaraan dan pemberdayaan perempuan yang digagas oleh CEDAW melalui Beijing Platform for Action dalam Fourth UN World Conference on Women (Hawk, Wynhoven, Mills, \& Gula, 2011)

Murniati Ruslan (2010) dalam jurnalnya "Pemberdayaan Perempuan dalam Dimensi Pembangunan Berbasis Gender" menyatakan bahwa lahirnya konteks pemberdayaan perempuan berawal dari problematika perempuan sebagai individu yang dipengaruhi oleh unsur-unsur sosialbudaya dan politik-pemerintahan. Berdasarkan latar belakang sosial-budaya, perempuan ditempatkan pada posisi yang kurang beruntung sejak mengemukanya imperialisme global. Pada umumnya para raja nusantara berhak memelihara banyak selir yang dipersilahkan untuk tinggal di istana. Peran selir melayani kebutuhan biologis sang Raja, namun yang sah diperistri sebagai permaisuri dan berhak melahirkan putra mahkota hanya satu serta pada umumnya berlatarbelakang sama dengan sang raja. Ketika terjadi peperangan, dan penaklukan wilayah kerajaan, perempuan (selir) juga dijadikan sebagai rampasan perang. 
Pada zaman penjajahan, perempuan merupakan komoditas ekonomi yang diperjual-belikan sebagai budak seksual atau pelayan/ abdi majikan yang memiliki kapasitas feodal -uang dan jabatan. Selain itu, penjajah dari Eropa -Belanda, Spanyol, dan Portugis- memelihara perempuan-perempuan dari kalangan masyarakat kelas bawah (petani) dan ekonomi lemah dengan tujuan memperluas pengaruh dan kekuasaannya di wilayah jajahan. Namun perempuan-perempuan yang dipelihara oleh para penjajah tidak diakui secara politik-administratif. Sehingga, tidak diperkenankan dibawa ke negara asal karena tidak memiliki hak kewarganegaraan apapun. Transaksi politik antara pihak kolonialis dan tokoh masyarakat juga menggunakan instrumen perempuan (pada waktu itu disebut dengan istilah Nyai) sebagai kompensasi agar jabatannya tidak diganggu. Dengan demikian, tradisi yang berkembang sejak zaman kerajaan menempatkan perempuan sebagai masyarakat kelas kedua yang tidak memiliki posisi tawar. Kebijakan imperialisme melegitimasi perempuan sebagai unit sosial yang kurang berperan dalam masyarakat dan justru menjadi objek kekerasan/ penindasan (Ruslan, 2010).

Perempuan menjadi pihak yang rentan dan kurang mendapat kesempatan dalam ruang publik. Betapa tidak, dalam sektor industri, perusahaan lebih menyukai memiliki aset karyawan laki-laki dibandingkan perempuan dengan alasan efisien dan praktis. Seperti yang kita ketahui bersama, laki-laki tidak perlu mengajukan cuti hamil, melahirkan, menyusui atau haid (maternitas). Jika pun perusahaan/ instansi mengakomodir pekerja perempuan, berdasarkan hukum internasional mereka harus menerapkan perlindungan terhadap hak reproduksi dan hak-hak pekerja perempuan berbasis nilai-nilai kesetaraan gender . Sementara, perempuan dalam bekerja terkendala dengan peran reproduksi dan aspek kultural lainnya, seperti jam bekerja yang tidak boleh menanggalkan tugasnya sebagai ibu atau istri (perspektif ketimuran). Akan tetapi, kosmopolitanisme gender menempatkan isu kesetaraan menjadi penting bagi studi sosialpolitik dan ekonomi. Perempuan tidak hanya sebagai objek pembangunan (sumber daya manusia/ modal pembangunan) tetapi juga merupakan subjek pembangunan (pengambil keputusan/ kebijakan/ inovator). Perempuan memiliki hak dan kesempatan yang sama dengan kaum pria untuk memaksimalkan potensinya dalam pembangunan dan terlibat secara aktif untuk merencanakan masa depannya (Baden, 2000; Lewandowski, 2015; Marwanti \& Astuti, 2012; Moser, 1993; Ruslan, 2010).

Secara khusus, pembangunan dimaknai sebagai proses berkemajuan untuk menciptakan kondisi yang menjamin harkat dan martabat manusia untuk kehidupan yang aman, damai, dan sejahtera (Kusumaningrum, 2016). Seperti yang ditekankan oleh PBB di mana pemberdayaan perempuan akan bermanfaat pada 5 (lima) aspek kehidupan: 1) 
Membangun ekonomi yang kuat, 2) Membentuk masyarakat yang adil dan damai, 3) Mencapai cita-cita pembangunan internasional yang berkelanjutan dan sesuai dengan nilai-nilai HAM, 4) Meningkatkan kualitas hidup perempuan, laki-laki, keluarga dan komunitas, dan 5) Mampu mewujudkan kegiatan usaha yang lebih produktif dan mapan (Hawk et al., 2011). Namun demikian, isu kesetaraan gender dan pemberdayaan perempuan yang merupakan perspektif global, masih menjadi tantangan bagi semua negara di tengah arus globalisasi yang menuntut percepatan dan konektivitas internasional, termasuk Indonesia.

Berdasarkan hasil observasi, perspektif masyarakat Jawa tradisional masih meyakini kapasitas perempuan di bawah lakilaki, terutama pada aspek mencari nafkah. Tradisi Jawa menularkan cara pandang bahwa perempuan makhluk yang lemah/ rentan dan perlu dilindungi serta dikasihi. Di sisi lain, perempuan memiliki peran khusus dalam rumah tangga yaitu sebagai "kawula wingking" - seseorang yang ditempatkan di 'belakang'/ bukan pada area publik (domestik/ rumah tangga). Perempuan dituntut untuk bertanggungjawab pada perannya sebagai ibu dan istri yang harus menguasai tugasnya untuk berpenampilan menarik (macak), bereproduksi (manak), dan mengolah makanan (masak). Tidak jauh berbeda dengan masyarakat di bagian timur seperti Papua, perempuan masih menjadi sub-ordinasi dari laki-laki. Perempuan belum leluasa mengembangkan kapasitas ekonominya secara mandiri. Selain itu, lingkungan sosial menempatkan perempuan lebih kepada mengatur rumah tangga daripada berperan pada sektor publik. Walaupun perempuan sesungguhnya dapat menjadi mitra strategis untuk mengembangkan perekonomian daerah/ pedesaaan melalui industri rumahan (home industry).

Tulisan ini menyajikan analisis sosial terkait peran perempuan pada kebangkitan ekonomi lokal. Bagaimana studi kasus berkembangnya UKM Kripik Tempe Sagu di Dusun Mrisi-Yogyakarta merupakan sebuah contoh sukses pemberdayaan kaum perempuan yang pada akhirnya berpengaruh terhadap berubahnya cara pandang dan dukungan masyarakat pedesaan terhadap peran perempuan dalam mencari nafkah.

\section{Metode}

Tulisan ini mengaplikasikan pendekatan penelitian kualitatif di mana penulis menyusun klaim (hipotesis) dari teori yang ada atau mempertimbangkan gambaran umum dari kehidupan sosial dan kemudian meneliti aspek tertentu dari gambaran umum itu untuk menguji sebuah teori. Adapun teknik pengumpulan data menggunakan observasi, studi pustaka, dan wawancara mendalam. Studi literatur diperoleh dari analisis sumber pustaka terkait subjek penelitian dan masalah pemberdayaan perempuan di Indonesia.

Subjek penelitian adalah 
manajemen UKM Kripik Tempe Sagu yang direpresentasikan oleh Pemilik Usaha dan Karyawan Produksi. Observasi dilakukan untuk mengamati aktifitas UKM Kripik Tempe Sagu di Dusun Mrisi RT 05, Kelurahan Tirtonirmolo, Kecamatan Kasihan, Kabupaten Bantul, Provinsi D.I. Yogyakarta (Lihat Gambar 1.).

\section{Perempuan sebagai Aset Pembangunan}

Penelitian ini menaruh perhatian pada perempuan sebagai entitas politik dan perubahan sosial. Politik Perempuan dimaknai sebagai bagaimana perempuan membuat keputusan dan langkah-langkah strategis demi mencapai kepentingannya dalam hidup. Perubahan sosial merujuk pada ruang lingkup interaksi masyarakat dan permasalahannya yang sangat dinamis dan kompleks. Perempuan dapat menjadi aktor politik apabila terdapat dukungan dari lingkungan dan kesempatan bagi perempuan untuk memaksimalkan potensi dan mengekspresikan pemikirannya. Oleh sebab itu, wacana pemberdayaan perempuan menjadi salah satu topik menarik untuk dikaji lebih mendalam.

Konsep Pemberdayaan Perempuan (Women Empowernment) dimaknai sebagai "A 'bottom-up' process of transforming gender power relations, through individuals or groups developing awareness of women's subordination and building their capacity to challenge it". UNDP menyatakan pemberdayaan perempuan dan kesetaraan gender menjadi strategi dalam mencapai citacita pembangunan milenium (MDGs) dan pembangunan berkelanjutan. Strategi ini diintegrasikan dalam kerjasama internasional untuk memberantas kemiskinan, mewujudkan pemerintahan yang demokratis, penanggulangan bencana, penanganan krisis, dan pengelolaan lingkungan hidup. Diharapkan perempuan mendapatkan ruang kebebasan dalam mengekspresikan pendapat dan memperoleh kesempatan seluas-luasnya untuk mengambil keputusan baik di ruang publik maupun pemerintahan yang berdampak pada keluarga, komunitas, dan masa depannya (UNDP, 2016).

Menurut Haryono Suyono (2003), strategi pemberdayaan perempuan diaktualisasikan dalam kebijakan nasional terkait program Keluarga Berencana (KB), di mana seorang ibu dapat mengatur jarak kelahiran dan memaksimalkan masa kehamilannya. Dengan cara itu, kaum ibu dapat ikut serta membangun keluarga, lingkungan serta mengembangkan sifat dan jiwa kewirausahaan dengan ikut serta dalam gerakan pemberdayaan ekonomi keluarga. Pemberdayaan perempuan dalam paradigma keluarga berencana berpijak pada filosofi pembangunan yang menjadikan perempuan sebagai mitra sejajar laki-laki. Upaya memberdayakan atau meningkatkan kualitas hidup perempuan ini diyakini sebagai solusi dalam mengatasi persoalan-persoalan diskriminasi perempuan (Ruslan, 2010).

Makna pentingnya perempuan dalam pembangunan nasional, diterjemahkan 
melalui ruang partisipasi politik yang lebih luas. Perempuan nyatanyan mampu dan layak untuk menjadi pemimpin daerah. Sebut saja, walikota Surabaya yang sangat berprestasi. Sosoknya tidak hanya sebagai ibu bagi anakanaknya, namun juga ibu bagi seluruh masyarakat Surabaya. Kebijakan Walikota Surabaya yang membubarkan lokalisasi Dolly diapresiasi sebagai langkah nyata pemerintah dalam memberdayakan perempuan sesuai dengan martabatnya sebagai manusia (HAM) dan menghilangkan upaya-upaya penindasan serta praktik manipulasi situasi yang nantinya akan mengembalikan warga masyarakat Dolly kepada jurang penistaan perempuan (komersialisasi seksual). Daerah bekas lokalisasi dijadikan sentra UKM yang diharapkan mampu membangun ekonomi masyarakat yang lebih baik dan lebih terhormat. Kebijakan untuk menata kawasan Dolly telah mengemuka sejak pemerintahan sebelumnya, namun baru pada periode kepemimpinan Ibu Risma, Surabaya berani mengambil keputusan besar untuk pembubaran Dolly yang sempat menjadi lokalisasi terbesar se-Asia Tenggara. Fenomena ini membuktikan bahwa perempuan lebih peka dan sensitif terhadap isu-isu kemanusiaan dan hal-hal yang menyangkut diskriminasi terhadap kaumnya. Dengan demikian, kebijakan Walikota Surabaya ini cenderung menggambarkan peran politik perempuan yang mempengaruhi isu perempuan dalam pembangunan.

\section{Peran Perempuan dalam Pengembangan}

\section{Potensi Ekonomi Pedesaan}

Tulisan ini menggambarkan aktifitas UKM Kripik Tempe Sagu yang diyakini sebagai sentra pemberdayaan masyarakat khususnya kaum perempuan. Berdasarkan hasil wawancara, usaha ini didirikan pada tahun 2012 dan mampu meraih omzet 50-60 juta per bulan dengan mempekerjakan hanya 3 laki-laki dan 6 perempuan (Lihat Tabel 1). Kehadiran UKM ini dianggap sebagai basis pemberdayaan komunitas yang mampu berkontribusi mengangkat derajat kehidupan dan kesejahteraan sebagian perempuan di Dusun Mrisi.

Usaha ini didirikan oleh Suwondo (41 tahun) bersama istrinya Saraswati Witarsih (40 tahun) pada tahun 2012 dan terdaftar pada Depkes melalui No.P-IRT 2153402011482-18. UKM ini berfokus pada pembuatan kripik tempe sagu dengan lingkup pemasaran meliputi beberapa daerah di pulau Jawa seperti

\begin{tabular}{|c|c|c|c|c|}
\multicolumn{7}{|c|}{ Tabel 1. Profil Pekerja Produksi } \\
\begin{tabular}{|c|c|c|c|}
\hline Nama \\
Karyawan
\end{tabular} & Bagian & Status & $\begin{array}{c}\text { Usia } \\
\text { (tahun) }\end{array}$ & Jumlah anak \\
\hline Partiyah & Penggorengan & Sudah menikah & 38 & 1 \\
\hline Walimah & Penggorengan & Sudah menikah & 45 & 3 \\
\hline Eryanti & Penggorengan & Sudah menikah & 41 & 3 \\
\hline Lastri & Penggorengan & Sudah menikah & 45 & 4 \\
\hline Sumarmi & Penggorengan & Sudah menikah & 43 & 2 \\
\hline Marsiyam & Penggorengan & Sudah menikah & 43 & 2 \\
\hline Ari & Pengemasan & Belum menikah & 18 & - \\
\hline Rujito & Pembuatan Tempe & Sudah menikah & 55 & 3 \\
\hline Saptono & Pembuatan Tempe & Sudah menikah & 50 & 2 \\
\hline
\end{tabular}

Yogyakarta, Magelang, Klaten, Solo, Sidoarjo, Bandung, dan Jakarta. Dalam perkembangannya UKM ini mengembangkan beberapa produk seperti 'tempe krispi' bermerk ABIL dan 'bakso goreng' dengan merk NAURA yang merupakan nama dari 
anak-anaknya. Tempe sagu ABIL dan bakso goreng NAURA cukup digemari masyarakat. UKM ini memperoleh pendapatan kotor 50-60 juta per bulan (Witarsih, 2015).

Gambar 1. Alamat UKM dan Lokasi Produksi

Berdasarkan hasil wawancara, pemilik usaha menerapkan sistem pengupahan yang terdiri dari gaji pokok harian, uang makan, insentif kehadiran dengan asumsi produksi dilaksanakan selama 6 (enam) hari penuh. Pemilik produksi menambah
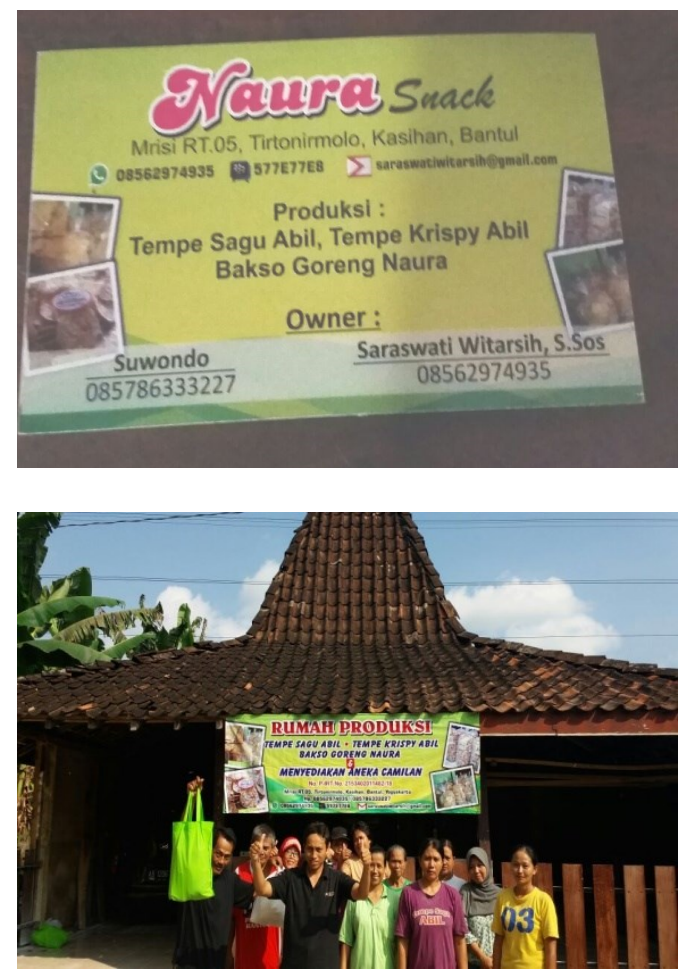

kesejahteraan karyawannya dengan menambahkan uang lembur yang diberikan setiap minggunya (pada hari Sabtu). Untuk memudahkan kinerja produksi, masing-masing tugas berada pada pengawasan para koordinator. Koordinator bertugas memastikan produksi berjalan dengan baik dan memimpin anggota-anggotanya bekerja sesuai prosedur. Bagi koordinator masing-masing jenis produk diberikan tambahan insentif.

Menurut pemilik usaha, mekanisme produksi telah menggunakan sistem pembagian kerja, di mana masingmasing bertugas sesuai dengan perannya dalam produksi. Bagian produksi harus melaksanakan tahapan-tahapan yang telah ditentukan sebagai berikut; 1) karyawan terlebih dahulu membuat adonan tempe sagu (puan), 2) Karyawan mempersiapkan adonan yang telah menjadi tempe untuk memasuki tahap penggorengan. Adapun tempe yang akan digoreng telah dipotong-potong dengan bentuk yang proporsional menggunakan mesin khusus, 3) Karyawan kemudian mempersiapkan bumbu sebagai tambahan cita rasa pada kripik sagu nantinya, dan 4) tahapan terakhir penggorengan hingga produk siap dikemas. Dalam sehari, UKM ini menghasilkan 30-40 Bal atau 60-80 $\mathrm{kg}$ tempe sagu siap didistribusikan sesuai pesanan. Tempe sagu diproduksi selama 3 (tiga) hari, mengingat dibutuhkan waktu lebih panjang karena melalui proses fermentasi (Witarsih, 2016).

\section{Pemilik UKM Tempe Sagu} merupakan bagian dari masyarakat berpendidikan tinggi. Sang suami Suwondo merupakan lulusan Diploma dan istinya Witarsih seorang Sarjana. Mereka berdua 
sempat tinggal di salah satu kota besar di Jawa Barat, bahkan Witarih sempat mengajar pada institusi pendidikan namun ia merasa hal tersebut tidak cukup mampu menjamin kesejahteraan ekonomi keluarga. Berangkat dari pengalaman Suwondo bekerja pada pendistribusian camilan dari produsen ke pasar tradisional, mereka berdua tertantang untuk membuat suatu produk yang unik, terjangkau, dan nantinya bisa dipasarkan sendiri. Harapan ini baru bisa mereka realisasikan di kampung halaman. Mereka mulai membuat bisnis camilan berbahan dasar tempe dan mempekerjakan ibu-ibu rumah tangga di dusun Mrisi (Witarsih, 2016).

Gambar 3. Kunjungan Studi Banding

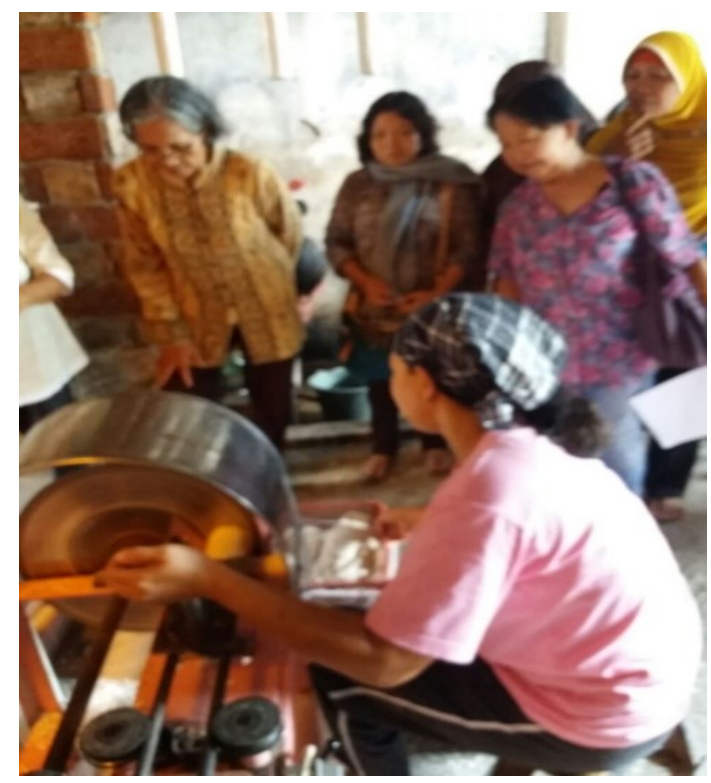

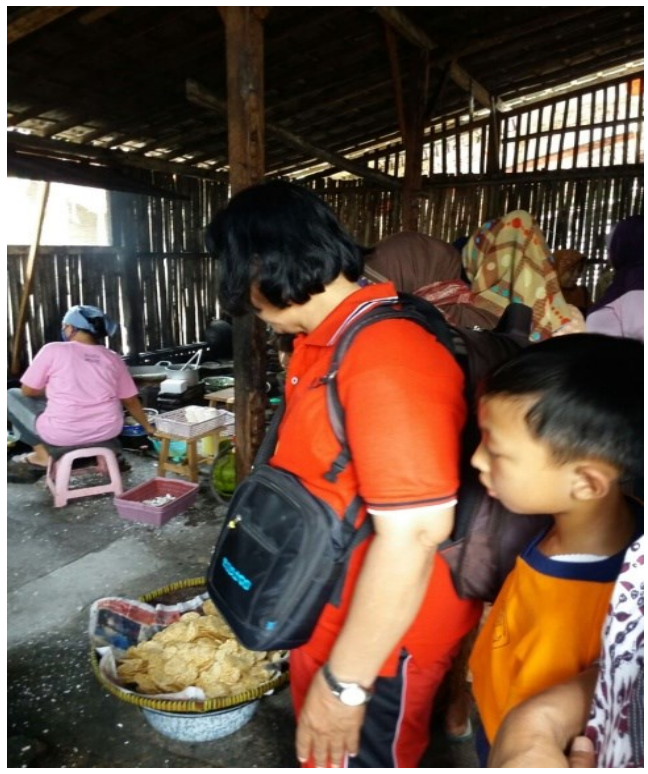

Kedua pasangan ini memiliki perspektif berbasis potensi kearifan lokal, di mana semua bahan baku dan sumber daya produksi diambil dari lingkungan di sekitarnya. Mereka melihat komunitas perempuan tidak semua mendapat kesempatan bekerja pada sektor publik karena latar belakang pendidikan rendah (SD-SMA). Para perempuan yang bekerja di UKM tersebut semua memiliki anak usia sekolah dan berkomitmen untuk membantu meningkatkan taraf hidup keluarga dengan membantu suami untuk menambah pendapatan. Rata-rata perempuan yang bekerja pada UKM suaminya berprofesi sebagai buruh dan wiraswasta. Dengan bekerja sebagai bagian produksi, para ibu-ibu rumah tangga ini mampu membantu keluarganya dengan penghasilan Rp 700.000Rp 900.000 per bulan tergantung lembur (Witarsih, 2016) .

Gambar 4. Karyawan Produksi 

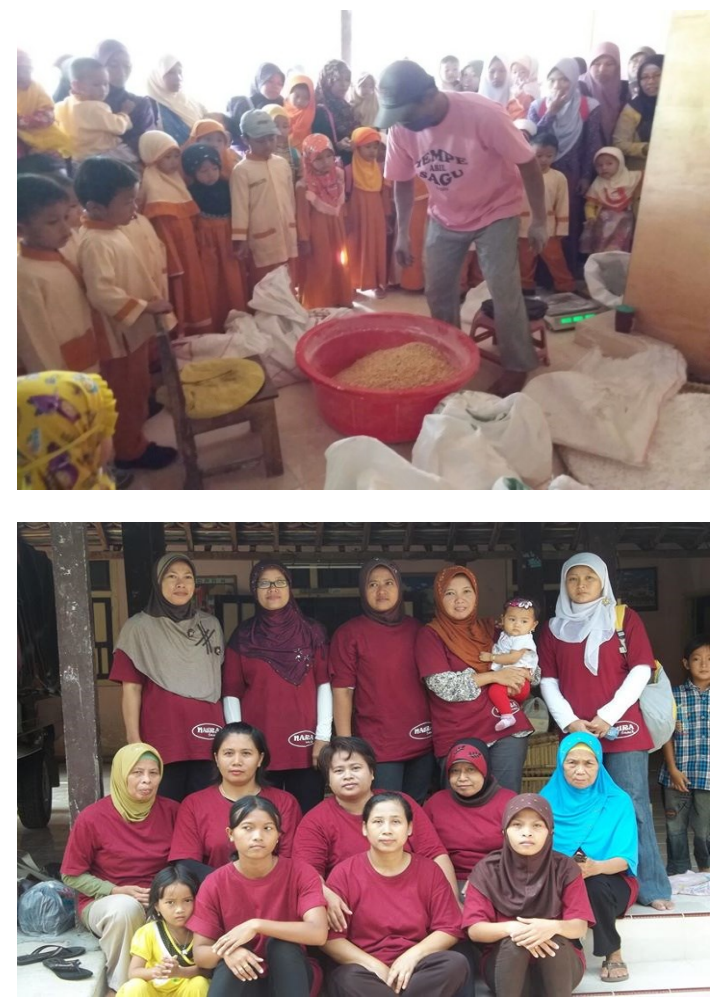

Eksistensi UKM ini mendapat dukungan penuh dari masyarakat Dusun Mrisi, mengingat cara pandang pemilik UKM masih selaras dengan adat budaya masyarakat lokal di mana perempuan memiliki peran utama untuk mengurus keluarga dengan baik. Sementara, perempuan yang bekerja tidak boleh melebihi jam kerja suaminya dan bertanggungjawab untuk merawat dan memperhatikan pendidikan anak-anaknya. Jam kerja harian untuk produksi kripik tempe dilaksanakan setiap hari, mulai Senin sampai dengan Sabtu dan dimulai pada pk. 08.0014.00. Adapun lembur pada umumnya hanya sampai pk 15.00. Sehingga, metode produksi dan kegiatan usaha kripik tempe ini diyakini mempunyai jam kerja yang 'ramah keluarga'. Bahkan UKM Kripik Tempe Sagu ini menjadi
Pengaruh Perspektif Pemberdayaan Perempuan dalam Kebangkitan Ekonomi Lokal: Industri Tempe Sagu di Dusun Mrisi-Yogyakarta

salah satu percontohan UKM dan ikon pariwisata berbasis kearifan lokal di Kabupaten Bantul.

Beberapa pihak telah berkunjung dan melakukan studi banding di UKM Tempe Sagu. Pada tanggal 27 November 2015 dihadiri 20 orang dari KWT Konggrahan Sleman. Selanjutnya pada tanggal 10 Maret UKM Tempe Sagu mendapat kunjungan dari UPPKS Desa Tirtonirmolo sejumlah 25 orang. Serta pada tahun 2016 setelah mengikuti Bantul Expo, beberapa orang dari BKM Tirtorahayu Tirtonirmolo turut menggali ilmu di UKM Tempe Sagu. Pada kunjungankunjungan tersebut tentunya sang pemilik akan ditanyai bagaimana peluang dan tantangan dalam pengembangan industri rumahan berbasis kudapan ini. Menurut Witarsih (2016), beban terbesar justru kepada nasib para karyawannya yang telah 5 tahun setia berjuang bersama. Dengan persaingan yang ketat antar industri kripik tempe, Witarsih mengembangkan varian yang berbeda untuk kripik produksinya.

\footnotetext{
"Kadang saya berpikir bagaimana agar tempe sagu ini tetap bisa menyerap tenaga mereka yang mungkin kebutuhan hidupnya menggantungkan pada usaha ini. Dari fenomena itulah mbak, saya saat ini terus berusaha agar tempe sagu ini tetap eksis di pasaran. Selain berdoa, saya berusaha berinovasi membuat produk pendamping tempe sagu. Alhamdulillah sampai saat ini ada 3 produk yang kami buat dan sedang uji coba untuk produk selanjutnya. Mungkin itu salah satu cara saya untuk tetap eksis di usaha ini mbak..."
} 
Gambar 5. Kunjungan dari PAUD
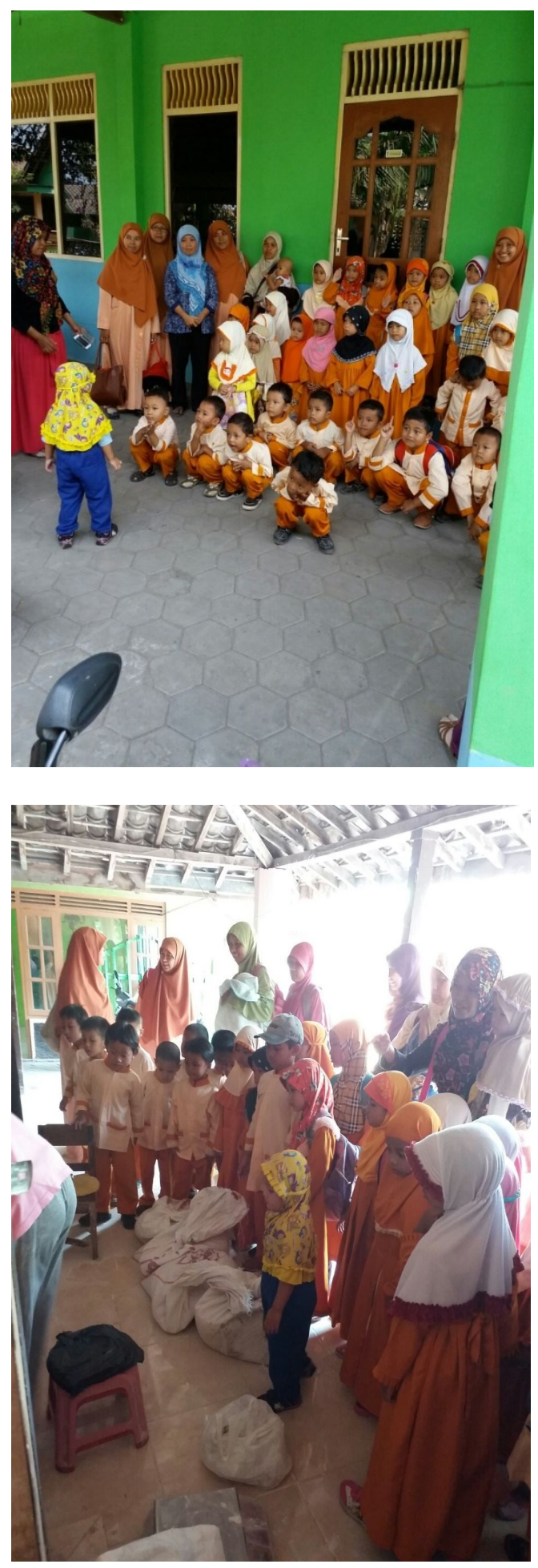

Pemilik UKM menyadari bahwa persaingan bisnis serupa cukup tajam. Dengan kehidupan yang serba terkoneksi dan berjejaring melalui dukungan internet, tidak dipungkiri kemunculan usaha sejenis semakin marak. Bahkan dijumpai dalam laman-laman online resep kripik tempe sagu dan usahausaha yang sama di Yogyakarta. Hal ini tentunya menjadi tantangan tersendiri bagi pemilik UKM. Namun pemilik UKM menaruh keyakinan dan optimisme bahwa masyarakat memiliki selera yang berbeda-beda terhadap produk komoditas yang sama. Dengan inovasiinovasi produk, usaha ini diyakini akan memperoleh tempat tersendiri di hati masyarakat. Selain itu, pemilik mengakui bahwa usaha ini tidak hanya berorientasi pada tujuan ekonomi semata namun juga tujuan sosial untuk membuka lapangan pekerjaan bagi para perempuan berpendidikan rendah yang kurang beruntung. Dengan harapan usaha ini akan mampu meningkatkan kesejahteraan masyarakat pedesaaan dan menjadi sentra pembelajaran bagi lingkungan di sekitarnya.

"Kalau mesin untuk menunjang produksi mungkin bisa saya terima karena bagaimana pun saya tidak mungkin menutup diri dari perkembangan teknologi karena persaingan yang semakin cepat. Tapi kalau harus mengurangi karyawan yang telah bertahun-tahun bekerja dengan saya kayaknya tidak, mbak. Dari awal saya merintis usaha adalah selain saya mendapat penghasilan juga ada keinginan untuk membantu atau memberdayakan ibu-ibu di lingkungan sekitar. Saya bisa seperti ini juga tak lepas dari peran mereka, dari doa mereka, dan dari kerjasama mereka selama ini. Rasanya saya tidak mungkin menghilangkan peran mereka 
Pengaruh Perspektif Pemberdayaan Perempuan dalam Kebangkitan

Ekonomi Lokal: Industri Tempe Sagu di Dusun Mrisi-Yogyakarta

meskipun solusinya adalah mesin yang canggih." (Witarsih, 2016)

Di tengah arus perdagangan bebas para pemilik industri rumahan tentunya harus bekerja ekstra keras bersaing dengan industri manufaktur/ pabrikan dengan komoditas sejenis. Pada umumnya solusi bagi UKM adalah subsidi alat produksi (mesin) dan teknologi mekanisasi yang canggih dan efisien. Akan tetapi, pemilik usaha UKM tempe sagu nyatanya bertahan pada prinsip industri rumahan yang tetap mempertahankan ibu-ibu rumah tangga berpendidikan rendah sebagai asisten produksi dan terkesan tidak peduli dengan faktor efisiensi yang digaunggaungkan oleh para pemikir ekonom klasik. Nilai-nilai normatif saling asih asuh dan gotong-royong di Dusun Mrisi semakin menguatkan masyarakat untuk bersama-sama membangun ekonomi keluarga dan pedesaaan secara keseluruhan.

\section{Kesimpulan}

UKM kripik tempe sagu yang menjadi studi kasus penelitian ini berkembang dari potensi masyarakat pedesaan yang tidak ingin menjadi tergerus arus kemajuan zaman. Kehadiran industri rumahan di Dusun Mrisi dianggap sebagai sentra pemberdayaan perempuan desa dan mendapat dukungan dari masyarakat di sekitarnya. Perempuan yang berpendidikan rendah pada awalnya dipandang sebelah mata karena tidak punya keahlian yang dapat membantu perekonomian keluarga. Namun para karyawan perempuan di UKM kripik tempe sagu di Dusun Mrisi ini mampu menjadi teladan bagaimana perempuan tetap memegang nilai-nilai sosial masyarakat dan menjalankan perannya sebagai ibu dan istri di samping bekerja sebagai pembuat kripik tempe. Kegiatan para ibu yang bekerja di UKM kripik tempe diapresiasi dengan baik oleh semua pihak karena usaha mereka mampu menularkan jiwa kewirausahaan dan mental mandiri bagi para perempuan yang berpendidikan rendah.

Lebih jauh, UKM yang dipimpin oleh seorang perempuan ini menjadi media pembelajaran bagi semua kalangan masyarakat di mana seorang ibu tetaplah harus menyadari fitrahnya untuk mengatur rumah tangga dan merawat anak-anaknya. Bekerja tidak harus melayani masyarakat di sektor publik tetapi bisa dengan berinovasi membuat produk yang mampu membuka lapangan kerja bagi komunitas yang rentan. Sehingga, bisnis kripik tempe ini memberikan kemanfaatan ekonomi dan juga sosial-budaya. 


\section{Referensi}

Baden, S. (2000). Gender and Development : Concepts and Definitions by Hazel Reeves and Sally Baden, 44(55).

Hawk, J. L., Wynhoven, U., Mills, L., \& Gula, L. (2011). The Women's Empowerment Principles - Equality Means Business initiative (second). United Nations Global Compact. Retrieved from http://www2.unwomen.org/ /media/headquarters/attachments/sections/partnerships/ businesses and foundations/women-s-empowerment-principles_en pdf.pdf? $\mathrm{v}=1 \& \mathrm{~d}=20141013 \mathrm{~T} 121445$

Kusumaningrum, D. N. (2016). Ekonomi Politik Perdagangan Internasional: Sertifikasi Keamanan dan Kualitas sebagai Kebijakan Standarisasi. In W. Hardyanti \& Nurudin (Eds.), Mozaik Kebijakan Sosial Politik Menuju Masyarakat Ekonomi ASEAN (pp. 81-90). Yogyakarta: Buku Litera.

Lewandowski, C. M. (2015). A conceptual framework for gender and development studies: from welfare to empowerment. The effects of brief mindfulness intervention on acute pain experience: An examination of individual difference (Vol. 1). https://doi.org/10.1017/ CBO9781107415324.004

Marwanti, S., \& Astuti, I. D. (2012). MODEL PEMBERDAYAAN PEREMPUAN MISKIN MELALUI PENGEMBANGAN KEWIRAUSAHAAN KELUARGA MENUJU EKONOMI KREATIF DI KABUPATEN KARANGANYAR, 9(1), 134-144.

Moser, C. O. N. (1993). Gender Planning and Development: Theory, Practice and Training. Feminist Review. https://doi.org/10.2307/1395333

Ruslan, M. (2010). PEMBERDAYAAN PEREMPUAN DALAM DIMENSI PEMBANGUNAN BERBASIS GENDER. Musawa, 2(1), 79-96. Retrieved from http:// download.portalgaruda.org/article.php?article=185721\&val=6439\&title=PEMBERDAYAAN PEREMPUAN DALAM DIMENSI PEMBANGUNAN BERBASIS GENDER

UNDP. (2016). Women's Empowernment. UNDP. Retrieved from http://www.undp.org/content/ undp/en/home/ourwork/womenempowerment/overview.html 